Life and Work 
This page intentionally left blank 


\title{
LIFE AND WORK
}

\author{
WRITERS, READERS, AND \\ THE CONVERSATIONS \\ BETWEEN THEM
}

TIM PARKS

Yale

UNIVERSITY PRESS

New Haven and London 
Published with assistance from the foundation established in memory of Amasa Stone Mather of the Class of 1907, Yale College.

\section{Copyright (C) 2016 by Yale University.}

All rights reserved.

This book may not be reproduced, in whole or in part, including illustrations, in any form (beyond that copying permitted by Sections IO7 and 108 of the U.S. Copyright Law and except by reviewers for the public press), without written permission from the publishers.

Yale University Press books may be purchased in quantity for educational, business, or promotional use. For information, please e-mail sales.press@yale.edu (U.S. office) or sales@yaleup.co.uk (U.K. office).

Set in Gotham and Adobe Garamond types by IDS Infotech, Ltd. Printed in the United States of America.

\section{Library of Congress Control Number: 2015951353 \\ ISBN 978-0-300-21536-6 (cloth : alk. paper)}

A catalogue record for this book is available from the British Library.

This paper meets the requirements of ANSI/NISO Z39.48-1992 (Permanence of Paper). 